\title{
SELF-ESTEEM OF RAPED WOMEN
}

\author{
Lucila Amaral Carneiro Vianna ${ }^{1}$ \\ Graziela Fernanda Teodoro Bomfim ${ }^{2}$ \\ Gisele Chicone ${ }^{3}$
}

Vianna LAC, Bomfim GFT, Chicone G. Self-esteem of raped women. Rev Latino-am Enfermagem 2006 setembrooutubro; 14(5):695-701.

This qualitative study shows the results of workshops held with health workers and public health users (raped women), aimed at raising these women's self-esteem and creating awareness among health workers who attend them. Neuro-Linguistic Programming techniques were used to bring back life experiences, which contributed to a re-reading and to minimize causal factors of low self-esteem. Themes like repugnance, fear and the fruit of rape; image and place; death; revenge; support and solidarity; domestic violence and bad care delivery to victims were addressed during the meetings. The stories were transcribed and analyzed, preserving content fidelity. Experiences lived at home and with loved and admired people, and mainly experiences resulting from the rape were responsible for the low self-esteem. The evaluations indicated the workshops as an opportunity to reflect, to return to normal life and to reconstruct self-esteem, for the raped women as well for the health workers who deliver care to them.

DESCRIPTORS: self concept; women; violence; rape

\section{AUTOESTI MA DE LAS MUJ ERES QUE SUFRI ERON VI OLENCI AS}

Este estudio cualitativo muestra resultados de oficinas de autoestima realizadas con usuarias (mujeres que sufrieron violencia sexual) y profesionales de instituciones de salud, con objeto de elevar la autoestima de esas mujeres y sensibilizar los profesionales que las asisten. Con las técnicas de la Programación Neurolinguística, surgieron experiencias vividas, favoreciendo nueva lectura y minimización de los factores causales de la baja autoestima. En los encuentros, fueron tratados temas como: asco, miedo y el fruto de la violación; imagen y local; muerte; venganza; apoyo y solidariedad; violación domestica y la mala atención a las victimas. Las historias fueron copiadas y analizadas, manteniendo la fidelidad del contenido. La responsabilidad por este problema de baja autoestima vino de experiencias negativas vividas en el hogar y con personas de nuestro circulo de afecto e admiración, principalmente las que surgieron con la violación. Las evaluaciones mostraron que las oficinas constituyen un medio de reflexión, retorno de la vida normal y reconstrucción de la autoestima, tanto para las victimas de violencia sexual como para los profesionales que las asisten.

DESCRIPTORES: autoimagen; mujeres; violencia; violación

\section{AUTO-ESTI MA DE MULHERES QUE SOFRERAM VI OLÊNCI A}

Estudo qualitativo que mostra resultados de oficinas de auto-estima realizadas com usuárias (mulheres que foram violentadas sexualmente) e profissionais da área da saúde, com o objetivo de elevar a auto-estima dessas mulheres e sensibilizar os profissionais que as atendem. Foram utilizadas técnicas da PNL, que possibilitaram trazer à tona experiências vividas, contribuindo para uma releitura e minimização dos fatores causais da baixa auto-estima. Nas oficinas foram abordados temas como: o nojo, medo e fruto do estupro; imagem e local; morte; vingança; apoio e solidariedade; violência doméstica e o mau atendimento às vítimas. As histórias foram transcritas e analisadas, mantendo a fidelidade dos conteúdos. Responderam pela baixa auto-estima experiências vivenciadas no lar e junto a pessoas pelas quais se nutria afeição e admiração, e aquelas advindas principalmente da violência sofrida. As avaliações apontaram as oficinas como oportunidade de reflexão, retomada da vida normal e reconstrução da auto-estima, tanto para as vítimas da violência como para os profissionais da saúde que as atendem.

DESCRITORES: auto-imagem; mulheres; violência; estupro

\footnotetext{
${ }^{1}$ Full Professor at the Paulista Medical School, e-mail: Ivianna@reitoria.epm.br; ${ }^{2}$ RN, Hospital São Paulo. São Paulo Federal University; ${ }^{3}$ RN, Hospital São Luiz
} 


\section{INTRODUCTION}

This project grew out of the researcher's and her research group's perception and experience in care delivery to women at basic health units and in the organization of self-esteem workshops that involved students, employees and clients. These research results allow us to affirm the close connection between the impact of social conditions on women's health and discrimination or social repression and sexual violence; these studies also indicate low selfesteem as a paramount factor caused by situations of exclusion, abandonment, need and threat experienced in relations, entailing negative consequences for quality of life ${ }^{(1-2)}$.

According to Maslow's hierarchy, after satisfying our physiological needs, we human beings feel safety needs, related to shelter and protection of our physique, family, home and community; next, we feel needs for esteem related to the ego - self-love, self-esteem, self-respect, confidence - need for recognition, appreciation and admiration ${ }^{(3)}$. The satisfaction of self-esteem needs makes individuals feel confident (about their value, strength, capacity and adequacy), more useful and needed in the world. Non-satisfaction, on the other hand, produces feelings of inferiority, weakness and impotence in individuals. The persistence of these feelings will lead to failures in their trajectory or different pathological processes ${ }^{(4)}$. Basic needs are interlinked and wellbeing depends on safety: the safer we feel in the environment we are part of, the more our self-esteem will be raised by confidence and respect and, consequently, continue high.

Accidents and violence derive from human action or omission, linked up with certain conditioning factors, such as social aspects, which cause health damage and are included in the group of "External Causes", which cover the following accident causes: traffic, work, falls, poisoning, drowning, among others; and intentional causes: aggressions and self-harm. If, on the one hand, the accident curve is directly proportional with technological and urban development, on the other, violence increases in human history and is directly connected with individuals' behavioral and situational matters ${ }^{(5)}$.

It is fundamental to clearly understand that the difference between genders is the organizing element of all inequalities between men and women in the public and private spheres, breaking with the traditional argument that tries to explain the malefemale difference by motherhood and rests on domestic values for women. However, insisting on this difference as the essence of womanhood means maintaining the power relation between genders. Women have increasingly conquered their rights in recent decades, although unequal relations between the sexes still continue, leading to serious problems, the worst of which are assassinations, often resulting from sexual violence against women ${ }^{(1)}$.

One of the most debated issued by the feminist movement is the acquisition process of female identity, which psychology has identified as the enigma of womanhood and, in this context, dependence. This has been pointed out as one of the main obstacles to the advancement of women. Things seem clearer when we refer to economic dependency, or to the living conditions needed to experience autonomy. However, this ground becomes much less solid when the reality of affective dependence appears ${ }^{(6)}$.

The authors ask the following questions: is women's self-esteem related to their financial and/or affective dependence/independence? Is it possible that men consider themselves that superior and, therefore, sexually violate women?

The dependence concept tends to cover different types of phenomena, including the one that means submission, i.e. woman's incapacity to maintain herself, conditioning her in function of the other; and dependence that makes woman adapt herself to the other person out of fear of abandonment. On the other hand, dependence can derive from the need for the other person to fill in affective lacks. While dependence is a bottleneck for women's liberation, lacks are inherent to the condition of social being. In other words, affective needs cannot be mixed up with the absence of autonomy that has placed women in a submissive relation in the public and private spheres ${ }^{(1)}$.

The authors believe that the achievement of autonomy and independence requires the satisfaction of affective and vital needs in general. Hence, women's problem is rooted in the fact that they are educated for other men and women to depend on them, relegating their affective needs to the background. That is exactly where the experience of the interior void occurs, as a feeling of lack of confusion that makes them feel foolish and weak and tend to compulsively depend on other persons. 
Violence against women is considered to be any injury caused by men, which results or can result in physical, sexual or psychological damage or suffering, including threats of these actions, or the arbitrary withdrawal of freedom, whether produced in public or in private life $e^{(1)}$.

Incidence levels of sexual violence, i.e. of rape* against women have been rising, causing physical and psychological sequelae and making victims more vulnerable to other types of violence, prostitution, drugs use, sexually transmissible diseases, gynecological diseases, sexual disorders, depression and suicide.

Sexual abuse is still connected with other behavioral problems, such as the abuse of alcohol and other drugs and unsafe sex with multiple partners ${ }^{(7-8)}$. This makes articulation between the health, education and safety areas fundamental, suggesting joint actions between the three institutional spheres. Moreover, organized groups are needed, with women working against violence, i.e. the implantation of programs to make professionals from these areas aware of the issue.

In Brazil, the reporting of sexual crimes remains low and the actual number of cases greatly exceeds police and judicial statistics. The Ministry of Health acknowledges that less than $10 \%$ of sexual violence cases are notified to the police station. The sexual violence scenario in this country produces serious repercussions for public health and for women's and adolescents' human rights, indicating the need to reduce existing administrative and cultural barriers with a view to full health service access ${ }^{(9)}$.

Most health services lack trained professionals to recognize signs of violence. This diagnosis requires a support group that goes beyond the health services, with a view to the solution of the identified problems and the easier surpassing of trauma resulting from this type of violence. Moreover, the health sectors should receive the victims, seeking to minimize pain and avoid other injuries. This justifies the realization of self-esteem workshops, which strengthens these women and helps them to dissociate themselves from the trauma they suffered. One example of the joint work developed by different health professionals is the Women's Support House Professor Domingos Deláscio, since 1999.
This research looks at the improvement of women's self-esteem through workshops that complement the care they received at the House, besides focusing on some interconnected premises, i.e. submission, domestic violence and particularly sexual violence, which has contributed to the deterioration of many Brazilian women's quality of life and health. Thus, this study aims to present the workshop as a tool to help women reconstruct their self-esteem and create awareness among health professionals.

\section{METHODOLOGY}

The research project was assessed and approved by the Research Ethics Committee at São Paulo Federal University. The registered participants were informed about its goal and their participation on a voluntary basis.

This is a qualitative study, because it intends to work with people, with related social actors and with specific groups (health service users and health professionals), and “... in the first place, these research subjects are theoretically constructed as components of the object of study"(10). Hence, qualitative instruments were used to achieve the proposed objective, to analyze the self-esteem process, using interdisciplinarity among different knowledge areas (crossed with gender relations) through life stories. This modality, which basically results from the contributions of Anthropology, Sociology and Communication, allows us to study the phenomenon more profoundly and to understand the complexity of factors intervening in the "culture of low self-esteem", mainly among women victims of violence; constructing a relationship of trust between these women and the researchers, in which they expose their situation and their life experiences, thus permitting a reflection and expectation of behavioral change in relation to their own self-esteem. Moreover, the theoretical-methodological reference framework of intersubjective relations permeates all participant social subjects, as well as the relation between researchers and subjects.

Hence, we believe that the validity of this study rests in its capacity to concretize the abstract object in all of its dimensions, in this case through the

* Rape: oblige a woman to have carnal intercourse through violence or serious threat 
different workshops, focus groups and the qualitative assessment process.

We report the results of five women's groups (workshops), each of which included five or six meetings, started with women victims of violence who looked for help at the Women's Support House Prof. Dr. Domingos Deláscio of São Paulo Federal University. Participants in each group also included five employees who normally receive and deliver care to these women, leading to professional awareness.

Starting from the premise that, traditionally, in our culture, young boys already receive more positive stimuli than girls, which will reflect in the formation of their personality and the construction of their self-esteem, we used Soeiro, who states that "if we continue without positive stimuli from our audiences for a long time, if we do not hear the sound of applauses during a considerable period, we will definitely feel bad. We tend to get depressed and feel insecure about our capacity. Hostile or indifferent audiences cause substantial damage to our self-esteem"(11).

The same author's studies gave rise to the use of drama techniques, based on Psychodrama, for the workshops, for participants to understand their own reality with a view to finding better answers to the new situations ${ }^{(11)}$. Moreover, the workshops were based on the principles of Neuro-Linguistic Programming $(\mathrm{NLP})^{(12-13)}$, which includes three ideas: - $1^{\text {st }}$ "Neuro", acknowledges all behaviors on the basis of the neurological processes of sight, hearing, smell, taste, touch and feeling, as the world is perceived through the five senses, "understanding of information before action".

- $2^{\text {nd }}$ "Linguistic", i.e. language to order thoughts, behaviors and communication among individuals.

- $3^{\text {rd }}$ "Programming", refers to the organization of ideas and actions to produce results.

Finally, NLP adopts an attitude of curiosity and fascination instead of starting from premises, bringing back the subjective experience and expressing the nature of the internal experience ${ }^{(12)}$.

Drama and life line strategies were used to allow the women to bring their experiences since childhood and reflect about them. This permits a rereading in order to elaborate new concepts about their condition of being a woman.

Thus, we developed the following modules: - Self-help for the women to survey their problems, which did not need to be connected to the violence they suffered;
- emergence of high self-esteem as one of the elements needed to exercise citizenship;

- assessment through the participants' experiences, told during the workshops.

In each group, games were used to approach the members; life story narratives through clay, drawing and newspaper and magazine clippings; information exchange about each participant's identity and feelings and exercises aimed at greater objectivity and personal valuation.

The researchers' reflection and action were supported by literature about the theme, about psychodrama and drama groups ${ }^{(11-14)}$, and about NLP ${ }^{(12-13)}$. They also participated in psychodrama and NLP groups.

The research group recorded, transcribed and analyzed all assessments of the research and the women's groups, so as to avoid distortions of their discourse and to allow each group to correct mistakes and mutually agree about differences. Focus groups sessions were held with professionals from the Women's Support House Domingos Deláscio, involved in care for these women. The situations were described, reedited and analyzed, based on the analytic framework that was pre-established by the researchers, starting from the answers that emerged. Next, the life stories were retold to order them in accordance with the analytic framework categories, but maintaining the characteristics of each life story's contents.

We attempted to understand the similarities and differences among the workshop participants' experiences by analyzing their life stories, based on the organization of the participant's experience by means of live testimonies ${ }^{(15)}$. In line with an internal logic that answers the main research questions, we used the participants' key words, which allowed us to establish connections in the studied process, in this case low self-esteem.

\section{RESULTS}

About the women

The length and physical appearance of the women who participated in the self-esteem workshops were in accordance with the standards for Brazilian women(around $1.60 \mathrm{~m}$ and 55 kilos), with a pleasant appearance and discrete clothing, neither attracting 
attention nor showing sensual manifestations. It is remarkable that most of them had a clear skin and long, dark hair, which was untied on the occasion of the rape; they were common girls who worked and/ or studied. One of them had a light mental impairment.

The NLP exercises helped the participants to talk about what and situations that bothered them and, thus, face unreported aspects, coping with and minimizing problems instead of fleeing from them. Some feelings can be highlighted, which are listed below together with the statements, for the sake of better content analysis:

- Repugnance, fear and the fruit of rape

After the whole trauma they suffered in the rape situation, the second big threat, besides the fear involved in the situation itself and the probability of catching diseases, is the fear of having generated a child - fruit of the traumatic event, who will not be considered as a child but as something that always reminds and reinforces the aggression, the feeling of impotence and repugnance towards the aggressor, as well as any object that can remind them of the fact. This is illustrated by the following statements:

... I panic each time I'm going to test for HIV.

... Thanks God I didn't get pregnant, because I couldn't stand bearing that thing.

... I felt such repugnance of my clothes that I threw them away.

- Image and place

Like in any trauma situation, and in rape cases in particular, some detail is associated with the scene, which the victim's mind starts to reject in other persons, on other occasions, in other places, and which usually becomes difficult to identify and minimize without technical help:

... I am horrified by tall and dark men.

... I can't see any man wearing a checked shirt.

... I can't see a gardener (in the condominium where she lives, people informed the author of the rape was a gardener).

... I always attempt to pay attention when I'm at the bus stop. I look around me, noticing anybody who's approaching.

... I walk in the middle of the street, I don't walk close to the wall anymore because there can be a gate and they can drag me in.

The victims tend to generalize, using universal quantifiers like "all" and "always" in their narratives, which should and can be discussed in order to remain limited to the situation they experienced ${ }^{(13)}$.

- Fear of death

Fear of death is undoubtedly the main responsible for raped women's lack of reaction, and is also the situation that most reminds them of the aggression. Fear can inhibit reactions that could even avoid the violence they suffered(16).

... it was horrible: that man held me and was threatening me all the time with a knife.

... I was returning home, when he caught my arm, threatened me with the knife and dragged me onto an empty piece of land.

- The pleasure of revenge

This really constitutes a key to work with the trauma of rape: in general, the women even revealed a certain degree of satisfaction when they found out about how the rapist ended up.

... the protector of my community said he has already made the guy disappear.

... I was relieved when I went to the police to file a complaint and the policeman said: if we catch him, he dies.

- Support and Solidarity

The victims were touched by the demonstrations of support and solidarity they received, and demonstrated that they started to attribute greater value to people's positive attitudes towards them ${ }^{(3)}$ :

... my father is really busy, but after I told him, he used to leave the office earlier and spend the afternoons with me, holding my hand and saying: you can sleep because I'm here. That was the best thing that could happen to me.

.... when I got the test results and everything was fine, it was very good and, with the help of my "kitty" (boyfriend), I managed to overcome the crisis, the revolt and the depression I felt.

... each smile, each word MO said (receptionist at the Women's Support House Dr. Domingos Deláscio) was very important at the moment of anguish and trauma, it was the most comforting and remarkable, not only for me, but for all other girls who arrived here to find help.

The trauma can not only be healed but, with appropriate advice and support, it can be transforming ${ }^{(16)}$. The trauma is able to be one of the 
most significant forces of psychological, social and spiritual awakening and evolution. The way we deal with trauma strongly influences our quality of life.

The final report also mentions the importance of adequate welcoming to women victims of violence, which again justifies the relevance of including health professionals who deliver care to victims in the workshops, as a way of creating awareness.

- Rape at home

In one of the violence cases caused by a relative, the young woman expressed the feeling that the family considered her as guilty, because she provoked the individual. In this case, improving selfesteem required harder and at the same time delicate work, as family support was not available, on the opposite. Overcoming the trauma was addressed as a challenge. Besides being vulnerable to street violence in general, women suffer domestic oppression and are often victims of hidden aggression, molestation and/or abuse by relatives and friends. This does not only cause trauma, but can continue for years and also leaves doubt about guilt ${ }^{(1)}$.

- Bad care delivery

Unfortunately, most hospitals and professionals are not prepared yet to deliver care to these patients:

... there was another rape in the care room. I stayed on a bed in the corridor, crying, all hurt and sore, and the doctor came with that thing (speculum) and she said stay still because I need to examine you and collect test material.

Domestic and/or sexual violence, emphasizing rape as a constant in all cultures and displaying higher incidence levels when related to abuse of alcohol and other drugs ${ }^{(1)}$, confronts all professionals involved with the challenge of recreating the language of health, redimensioning the space of the disease and people, each of whom lives her story in different contexts, with different needs, but with equal rights to express their opinion about the way

\section{REFERENCES}

1. Vianna LAC, Oliveira EM. A violência começa na gravidez. FEBRASGO； 1998.

2. Vianna LAC, Bomfim GFTB, Chicone G. Auto-estima dos alunos de graduação em enfermagem. Rev Bras Enfermagem 2002 setembro-outubro, 55(5): 503-8. they want to be treated and helped in the situation they experienced.

About the workshops

The workshops revealed that these women like undergraduate nursing students in an earlier study ${ }^{(3)}$, responded to experiences at their homes, caused by brothers, fathers and people for whom they had felt affection and admiration in childhood, by means of low self-esteem. They evidenced negative memories about the violence they had suffered.

We observed that understanding and acceptance by boyfriends, husbands, partners and the whole family support made it easier for these women to recover their normal life and reconstruct their self-esteem.

Individual evaluations indicated the workshops as an opportunity to reflect, change attitudes and perceive new roads ahead. In our opinion, one of the positive points in this study was the opportunity to prepare three women attended at the Women's Health House of São Paulo Federal University, who were motivated to multiply the selfesteem workshops in their communities.

The most noticeable situation in the group of employees was one professional's statement, during one of the sessions, revealing that she had asked transference to another service because she could not stand so much suffering anymore. In response, the women who participated in the groups opposed her attitude and convinced her of her importance to welcome the victims at the House, at such a discouraging time.

We believe that this research and the selfesteem workshops should continue, in order to improve the self-esteem assessment method before and after each cycle, i.e. in terms of "minimizing the phantom" of the rape situation, besides offering support to other support groups for women victims of violence, as a way of helping them to better cope with the situation and also as a way of preparing professionals who deliver care to these women.
3. Maslow A. Motivacion y personalidad. Ba: Sagitário; 1970.

4. Andrade D, Agerami ELS. A auto-estima em adolescentes com e sem fissuras de lábio e/ou de palato. Rev Latino-am Enfermagem 2001 novembro-dezembro; 9(6):37-41.

5. Mello Jorge MHP, Gawryszewski VP, Latorre MRDO. Análise dos dados de mortalidade. Rev Saúde Pública 1997; 31(Suppl 4):5-25. 
6. Eichenbaum EL, Orbach S. Qué quieren las mujeres? Madrid: Ed. Revolucion; 1987.

7. Ministério da Saúde (BR). Prevenção e tratamento dos agravos resultantes da violência sexual contra mulheres e adolescentes. Brasília (DF): Ministério da Saúde; 1999.

8. Weaver K, Maddaleno M. Youth violence in Latin América: current situation and violences prevention strategies. Rev Panam Salude Publica 1999; 5(4/5):388-43.

9. IPAS BRASIL [página na internet]. Rio de Janeiro: IPAS; c2001-2006. [atualizada em 27 fevereiro 2006; acessada em 2005]. Galli B, Adesse L. Reduzindo barreiras para o exercício dos direitos humanos e a auto-determinação sexual e reprodutiva das mulheres em situação de violência sexual, [2 telas]. Disponível em: http://www.ipas.org.br/arquivos/ violencia_bia2005_2.pdf.

10. Minayo MCS. O desafio do conhecimento. Pesquisa qualitativa em saúde. São Paulo (SP): UCITEC ABRASCO; 2000.

11. Soeiro AC. Realidade emocional: ajudando o homem a conquistar a realidade desejada. São Paulo (SP): Senac; 1999.

12. O'connor J, Seymour J. Introdução à programação neurolingüística: como entender e influenciar as pessoas. São Paulo (SP): Summus Editorial; 1995.

13. Andréas S, Faulkner C. PNL a nova tecnologia do sucesso. 6a ed. Rio de Janeiro (RJ): Campus; 1995.

14. Soeiro AC. Psicodrama e psicoterapia. São Paulo (SP): Ágora; 1995.

15. Bourdieu P. O poder simbólico. São Paulo (SP): Bertrand Brasil; 1989. Coleção memória e sociedade.

16. Levine PA, Frederick A. O despertar do tigre: curando o trauma. São Paulo (SP): Summus; 1999. 